\title{
John's prologue: Christological and doxological significance for the Johannine narrative ${ }^{1}$
}

\author{
Nathan Hahn \\ Department of New Testament and Related Literature \\ Faculty of Theology and Religion, University of Pretoria, South Africa \\ ORCID ID: https://orcid.org/0000-0002-4658-2523 \\ Ernest van Eck \\ Department of New Testament and Related Literature \\ Faculty of Theology and Religion, University of Pretoria, South Africa \\ ORCID ID: https://orcid.org/0000-0003-3810-4190 \\ E-mail: ernest.vaneck@up.ac.za \\ DOI: https://doi.org/10.46222/pharosjot.102029
}

\begin{abstract}
This article presents a literary exegetical analysis of the prologue (John 1:1-18) of the Johannine narrative with special attention to the author's (narrator's) point of view. The author sets the tone of his gospel and writes with literary beauty while showing his theological points of view that will be seen throughout his narrative to follow. He presents Jesus as the eternal tóyos of God, and thus provides a unique point of view toward the Son of God of the Father who exists from eternity past with God the Father. Merely by studying, reflecting on, and remembering the Gospel's prologue, the reader can understand and relate to the Christological and doxological significance of the Johannine narrative.
\end{abstract}

Keywords: John; John 1:1-18; John's prologue; Christology; doxology, narratology.

\section{Introduction}

The author of John most probably has written the prologue (John 1:1-18) to serve as an introduction to his gospel. It contains a number of important themes consistent with the rest of the gospel, including life (John 1:4), light and darkness (John 1:5, 7-9), witness (John 1:7-8, 15), world (John 1:10), belief and unbelief (John 1:11-12), and grace and truth (John 1:14, 17). Thus, the reader is able to see the connection between the prologue and the rest of the narratives.

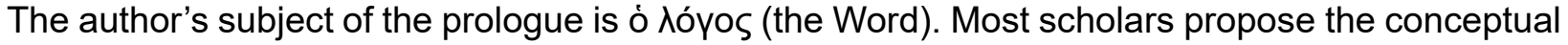
background of ó Nóyos into three sources, namely Greek philosophy (Stoicism, Philo), the personification of wisdom, and the Old Testament. ${ }^{2}$

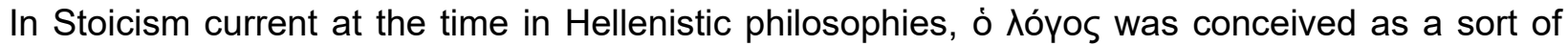

\footnotetext{
${ }^{1}$ This article represents a reworked version of aspects from the PhD-thesis of Nathan Hahn, titled Anonymous minor characters in the Johannine narrative: The Christological and doxological significance of the characterization in John 4, 5, and 9, in the Department of New Testament and Related Literature, University of Pretoria, with Prof. Dr. Ernest van Eck as supervisor.

${ }^{2}$ Keener (2003:339-363) provides in-depth discussions of ó ᄉóyos in Gnosticism, Hellenistic philosophy,

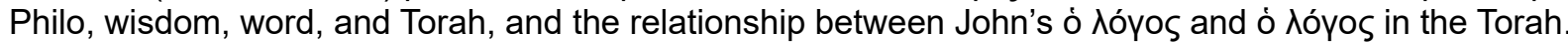


cosmic reason. It gave order and structure to the operation of the universe as an impersonal governing principle. According to the thought at the time, a bit of universal ó ᄉóyos resided within people who must live within it to attain dignity and meaning. It is doubtful, however, that this definition constituted the author's primary conceptual foundation (Köstenberger, 1999:52). Such ó $\lambda$ óyos, Kim notes, "has no concept of a personal God, no place for historical divine acts in the incarnation, no radical view of sin, no idea of ethical renewal through the ministry of the Word and Spirit, and no hope of the resurrection and eternal fellowship with God in His kingdom" (Kim, 2009:425).

Another proposed meaning of ò $\lambda$ óyo $\zeta$ is the personification of wisdom in wisdom literature such as Proverbs 8:22-31, where wisdom is presented as a divine being. Wisdom claims preexistence and participation in God's creative activity. Late in the period of the Hebrew Scriptures and beyond that period through the first century, Jewish speculation about wisdom related it to the Torah, the

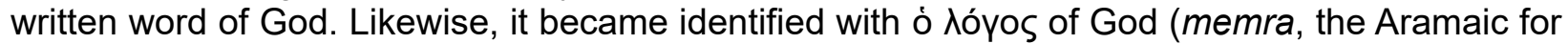

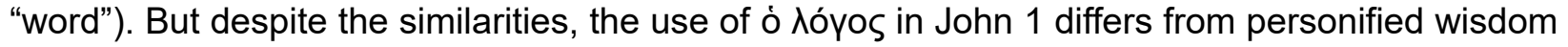
in several respects. ${ }^{3}$

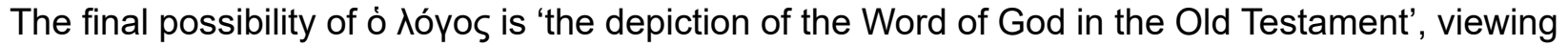
the prologue of John's gospel with a Hebraic background rather than a Hellenistic one (Köstenberger, 1999:54). This sees the origin of ó Aóyos as the Old Testament and the Hebrew term דָּ (dabar). Further supporting the Hebraic background is the author's possible deliberate echoing of the Hebrew Scriptures by employing the phrase "in the beginning" to open the gospel,

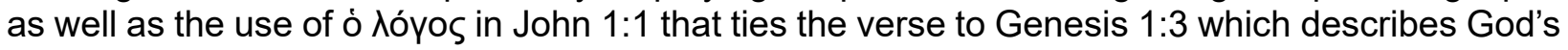
creative acts by the powerful command of His word. The author's adaptation of Isaiah 55:9-11 for his Christological framework has also been proposed as the background of ó $\lambda$ óyos in his gospel (Köstenberger, 1999:54). ${ }^{4}$

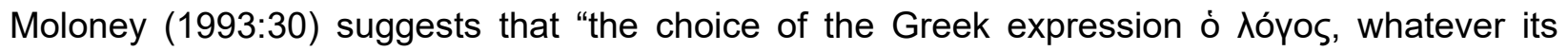
background, allows the author to hint to the reader that from the intimacy between the Word and God which has been described, 'the Word' will now be spoken. A word is essentially about communication. The modality of that communication has not been indicated, but if there is the Word, then it exists to say something". Harris (1994:91) summarizes well:

Why did John choose to call Jesus the Logos in the prologue to his Gospel, and what did he mean by it? As to why the term was used, the answer probably lies with John's audience. John gave no explanation of the Logos, apparently assuming his readers would understand the idea. Greek readers would probably think he was referring to the rational principle that guided the universe and would be shocked to find that this

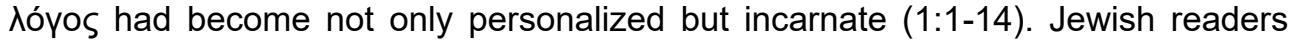
would be more prepared for some sort of personalized preexistent Wisdom, but they

\footnotetext{
${ }^{3}$ Köstenberger (1999:53) explains the differences in three points: 1) Wisdom literature presents wisdom not as a second person of the Godhead but merely as a divine attribute already present as creation. Jesus on the other hand is portrayed not merely as "with God" (John 1:1-2), but also Himself God (John $1: 1)$; 2) Wisdom is not cast as a person, but merely a concept that is personified, a common literary device. But in John the exact opposite is present: Jesus, a real person, is presented in conceptual terms as ó $\lambda$ óyos; 3 ) The fact remains that John did not use the term oọía (wisdom) but the expression o Aóyos.

${ }^{4}$ Köstenberger (1999:54) also argues that Isaiah 55:9-11 is God's personified Word, not Wisdom. He observes three parallels: 1) ó $\lambda o ́ \gamma o \zeta$ is sent by God to accomplish a particular divine purpose; 2) It unfailingly accomplishes this purpose; 3) Afterward it returns to God who sent it.
} 
too would be amazed at the idea of incarnation. John presented Jesus as the true Logos as preparation for his own presentation of Jesus as the Son of God.

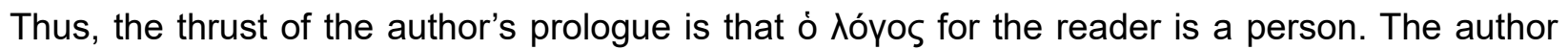
claims that $\lambda$ óyo $\zeta$ is not a category of religious experience, nor is it speculative religious mythology. It is the person, fleshed, living, historical Son of God, Christ. Jesus Christ is the incarnation of the

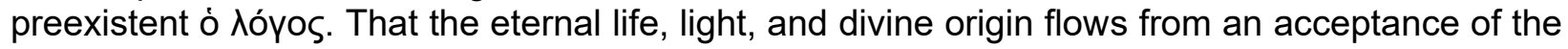
story of the unseen God revealed by the incarnated $\lambda$ óyos. The reader has been told who Jesus is and what He has done. The author tells how the action of God has taken place in history.

\section{Literary structure of the prologue}

Some scholars, in describing the literary structure of the prologue, follow a movement in time, from preexistence (John 1:1-2) into creation (John 1:3-5), proceeding through the story of human condition until the incarnation (John 1:6-14) and then the subsequent reception of the incarnate

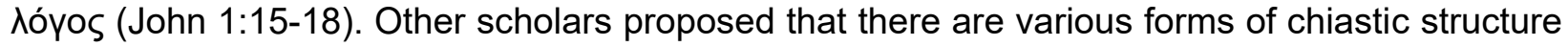
of the prologue. One proposed by Culpepper (1980:1-31) seems to be the most thorough, and thus serves as a good model for discussion:

A. The Word's activity in creation (John 1:1-5)

B. John's witness concerning the light (John 1:6-8)

C. The incarnation of the Word (John 1:9-14)

B. John's witness concerning the Word's preeminence (John 1:15)

A. The final revelation brought by Jesus Christ (John 1:16-18) ${ }^{5}$

\section{The Word's activity in creation (John 1:1-5)}

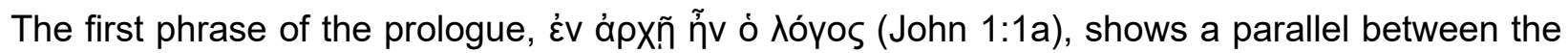
opening of the narrative and the biblical account of the beginnings of history in Genesis $1: 1$. Before the beginning of the history there was only God, but the author claims that even then ñv ó $\lambda$ óyos

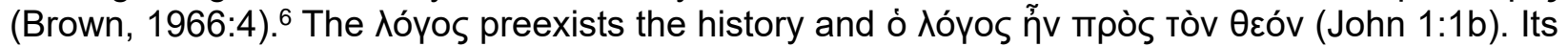
'existence is placed outside the limits of time and place, neither of which existed ćv ápxñn' (Moloney,

${ }^{5}$ Köstenberger (1999:57) agrees and adopts Culpepper' suggestion, suggesting a chiastic structure in which John 1:12 is the center of attention. Seo (2007:16) outlines his chiastic structure into seven units according to Christological themes:

A - The Word was God (John 1:1-2)

$B$ - In the Word was life (John 1:3-5)

C - Through the Word all men might believe (John 1:6-9)

D - To those who believed in the Word (John 1:10-14)

C' - This was He (John 1:15)

B'- Grace and truth came through Jesus Christ (John 1:16-17).

A' - God the One and Only is at the Father's bosom (John 1:18).

Meanwhile, although it is probable that the author designed a chiastic structure, some scholars, like Kim 2009:428) proposed the outline for the sake of the dividing passage according to a thematic analysis:

A - The origin and nature of the Logos (John 1:1-5)

$\mathrm{B}$ - The witness to the Logos (John 1:6-8)

C - The manifestation of the Logos (John 1:9-13)

D - The revelation of the Logos (John 1:14-18).

${ }^{6}$ Brown (1966:4) argues that the word $\tilde{\eta}$ V in John 1:1 conveys the notions of existence, relationship, and

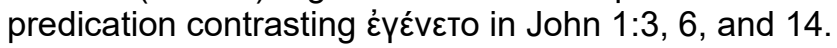


1998:35). The ᄉóyos preexists for a relationship with God. From the start the author chose the

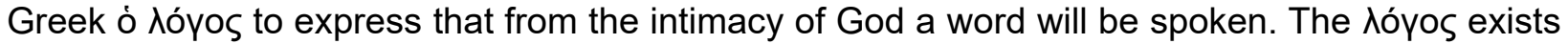
to say God's revelation. The term $\theta \varepsilon$ ò $s$ is familiar to the reader or implied reader of the Johannine narrative as a reference to the God revealed in the Old Testament, and the $\theta \varepsilon$ ò occurs in Genesis $1: 1$ to refer to the Creator. The author's favorite expression for $\theta \varepsilon o ̀ s$ in his narrative is татń $\rho$ of Jesus (John 1:14, 18; see Köstenberger, 2004:28).

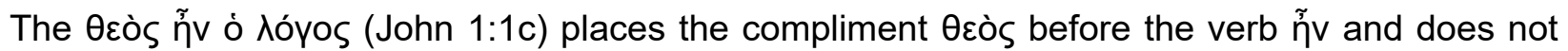
give it an article. This means that the author avoids saying that ó $\lambda$ óyos and $\theta \varepsilon o ̀ s$ were one and the same thing. ${ }^{7}$ It indicates that ó $\lambda o ́ y o s$ and $\theta \varepsilon o ̀ s ~ k e e p$ their uniqueness, despite oneness due to their intimacy. Having distinguished ó ᄉóyos from $\theta \varepsilon$ s̀s, the author shows that they are God. Of course, calling ó $\lambda$ óyos God extended the boundaries of Jewish belief in Jehovah God (see

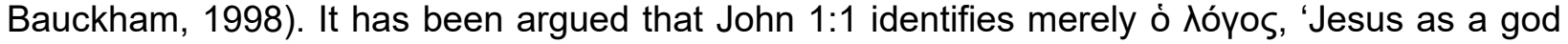

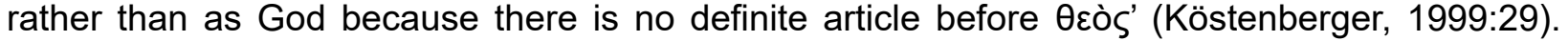
However, this is unworthy discussion as Köstenberger explores for several reasons. ${ }^{8}$

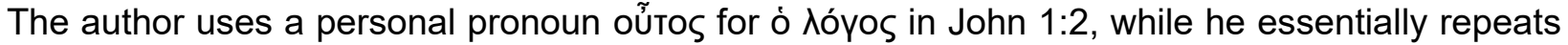
what has already been claimed in John 1:1. Now the reader understands more of the contents of John 1:1, providing 'closure as well as preparing the reader for 1:3'. (Carson, 1991:118). Who might oũTos be? The author insinuates an eventual revelation that will take place in history by

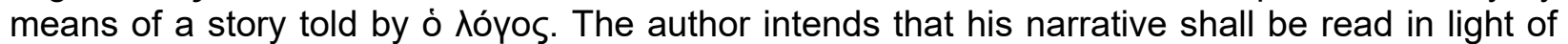
these first two verses (Barrett, 1978:156). ${ }^{9}$ So far he claims that as the incarnated $\lambda$ óyos, Jesus alone is God who has come to the world. No other can stand alongside Him or take His place. Jesus shares in the infinity of God. This does not mean that people cannot know Him, but they cannot have complete knowledge of Him. He must always be in the center of the believer's approach to God, his thinking about God, and his relating to God (John 14:6).

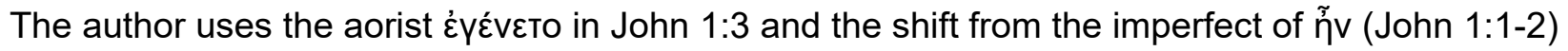

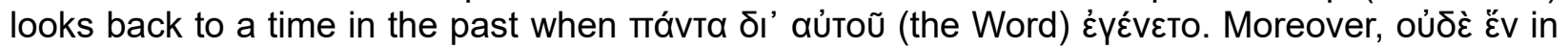
creation took place without ó $\lambda$ óyos. The author conveyed that in the beginning the revealing act

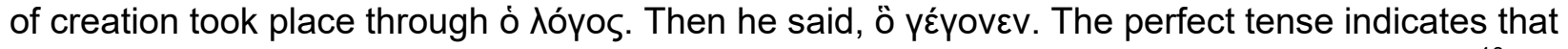
the creation took place in the past, but the significance of its plot continues into the present. ${ }^{10}$

The Aóyos speaks out of intimacy with God and makes God known, both in creation and in the

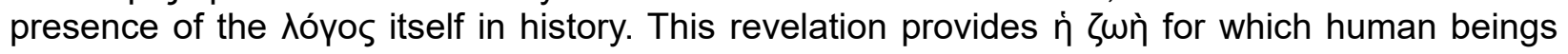

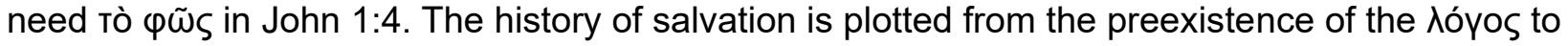

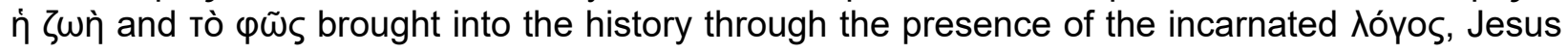

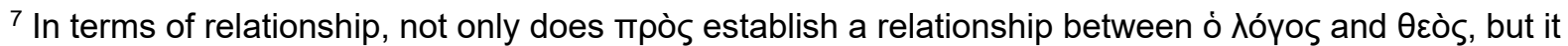
also distinguishes the two from each other (Brown, 1966:5, see also see Köstenberger, 2004:5).

${ }^{8}$ After he states three reasons, Köstenberger (2004:28-29) continues: "Nevertheless, the force of the anarthrous $\theta \varepsilon o ̀ \varsigma$ is probably not so much that of definiteness as that of quality: Jesus shared the essence of the Father, though they differed in person. Everything that can be said about God also can be said about the Word." MacLeod (2003:58-62) also argues strongly against the assertion Jesus is a god, surveying many scholars' theological, literary, and grammatical reasons.

${ }^{9}$ Barret (1978:256) also states that "the deeds and words of Jesus are the deeds and words of God; if this be not true the book is blasphemous."

${ }^{10}$ The emphasis of John 1:3 is to point to creation, not incarnation. The author asserts that mávia ("everything in creation") owes its existence to ó Aóyos (see Carson, 1991; Morris, 1995:71; Ridderbos, 1997:37).
} 
(John 1:14). The author affirms that the revelation brought by the $\lambda$ óyo $\varsigma$ is coming into the world.

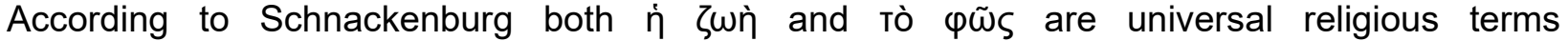
(Schnackenburg, 1990:242-244), but Culpepper (1983:180-198) argues that they are rooted in Old Testament teaching. At creation, tò $\varphi \tilde{\omega} \varsigma$ was God's first creative act (Gen 1:3-5). Later, God placed lights in the sky to separate $\varphi \tilde{\omega} \varsigma$ and бKoтía (Genesis 1:14-18; see Morris, 1995:74). The

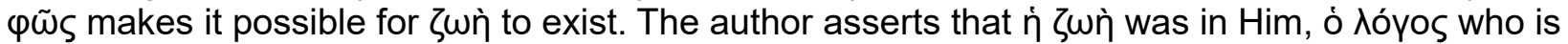
the source of $\zeta \omega \grave{~ a n d ~} \varphi \tilde{\omega} \varsigma$.

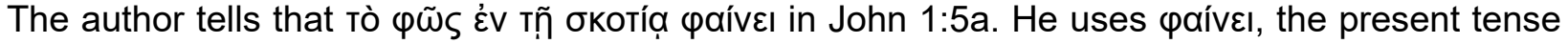

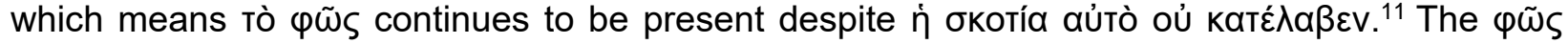
came when ó 入óyos incarnated in the world and now shines (Ridderbos, 1997:39). Thus, the reader may recognize tò $\varphi \tilde{\omega} \varsigma$ keeps shining in spite of the hostile reception it received. The author speaks of how human beings respond to the revelation of God that takes place in the Nóyos, Jesus Christ. The бкотía is the world estranged from God in Johannine narrative, spiritually ignorant and blind dominated by Satan (Schnackenburg, 1990:245.)

It is evident that John used the opening verses of his narrative to firmly set in place the Christological planks of the framework for a worldview. As the incarnated $\lambda$ óyos, Jesus Christ is God, and He created all things. To reject this worldview is to choose darkness. Those who choose darkness do not want Christ as their Creator and Sovereign.

\section{John's witness concerning the light (John 1:6-8)}

The author gives a more narrative description of the figure and role of John the Baptist in John 1:6-8. Although many scholars consider it a secondary addition to the prologue, this section is essential to the prologue's structure and message. As the Aóyos's involvement in the events of history is found in John 1:3-5, the author continues to introduce another historical figure who

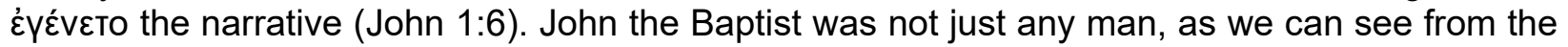

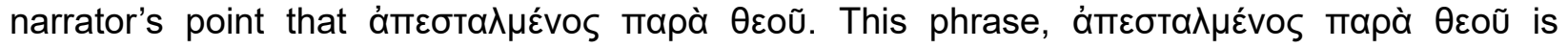
reminiscent of the 'Old Testament description of a prophet' whose 'role was a spokesperson for God' (Brown, 1966:8). This is a very unique claim, since nobody else in Johannine narrative is

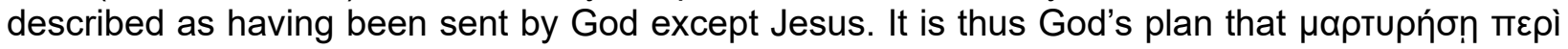

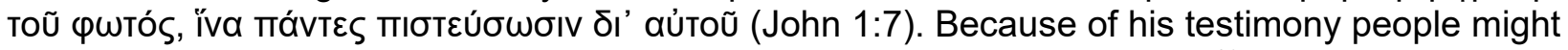

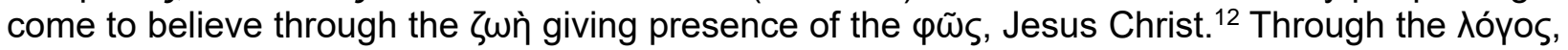
all things were created (John 1:3). Now it is God's purpose that people might believe through John the Baptist's testimony (Brown, 1966:8-9; see also Carson, 1991:121; Barrett, 1978:159).).

Köstenberger states well in regard to the witnesses, "This role of eyewitness is both vital and humble. It is vital because eyewitnesses are required to establish the truthfulness of certain facts. Yet it is humble because the eyewitness is not the center of attention. Rather, eyewitness must testify truthfully to what they have seen and heard - no more and no less. The Baptist fulfilled this task with distinction" (Köstenberger, 2004:33).

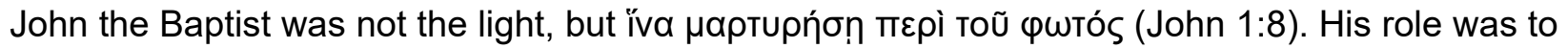

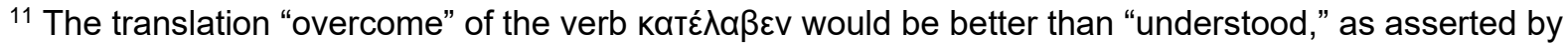
many scholars such as Morris (1995) Moloney (1998), and Schnackenburg (1990). Carson (1991:138) thinks the author might have both meanings in mind.

${ }^{12}$ Although it is not actual ultimate outcome, the desired result of John the Baptist's witness is that all might believe in Jesus (see Barrett, 1978:159; Carson, 1991:121).
} 
give a witness to the light. Therefore, the reader must not be confused. John the Baptist was a great man, but he was not the light. While he is cast in a positive light as a witness to Jesus, John the Baptist is not the light, but rather a lamp (John 5:35; see Brown, 1966:28; Morris, 1995:81; Ridderbos, 1997:42; Keener, 2003:393). Moloney (1998:37) states: "The Prologue is now firmly anchored in history and, like vv. 1-5, its second section (vv. 6-14) opens with a description of the Word and a careful separation of the role of the Baptist from the role of the Word."

This section of the prologue has significance both theologically and practically. The author claims again Jesus alone is the true light of divine revelation. John the Baptist is a role model of a witness for Jesus. Dodd argues that a threefold schema in this section controls the subsequent sections of John 1 that deal with John the Baptist. ${ }^{13}$

\section{The incarnation of the Word (John 1:9-14)}

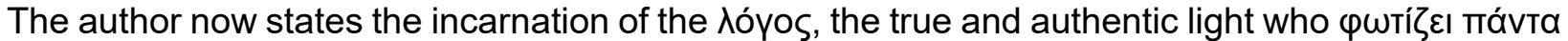

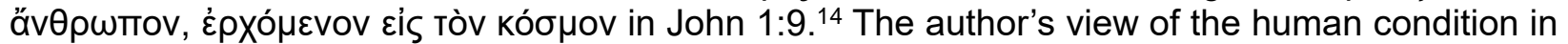

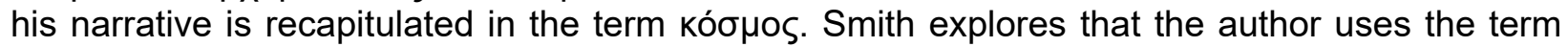

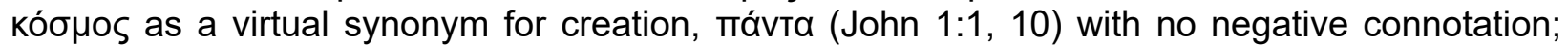

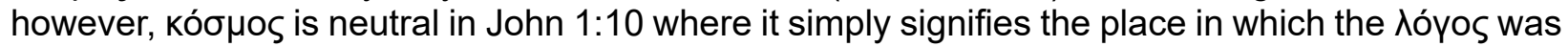

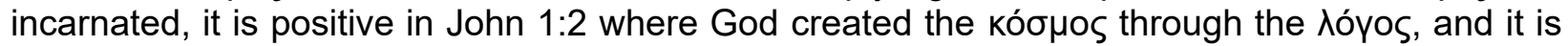

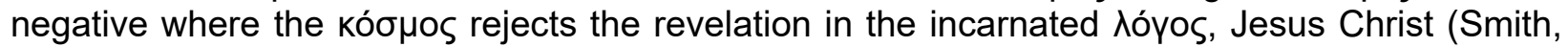
1995:80-81).

As tò $\varphi \tilde{\omega} \varsigma$ тò á $\lambda \eta \theta i v o ́ v$, Jesus is presented as the source of $\varphi \tilde{\omega} \varsigma$ that enlightens people. The incarnation of the $\lambda$ óyos has been portrayed in the first section of the Prologue (John 1:1-5) and is reiterated here in John 1:9-10. This of course does not suggest the universal salvation of all people, because the author does not speak of internal illumination in the sense of special revelation, 'but of external illumination in the sense of objective revelation requiring a response' (see Brown, 1966:9; Köstenberger, 2004:35). Not all people accept the light, 'though it was

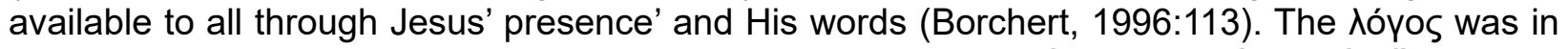

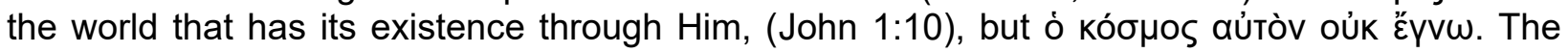

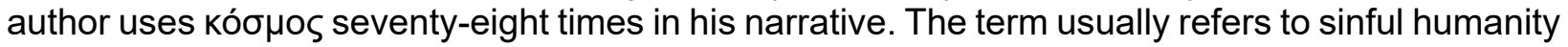

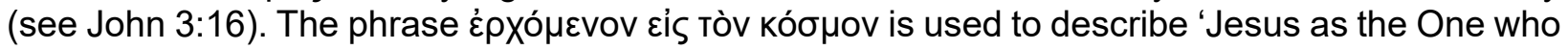
enters the world from the outside' and returns to His place of 'the presence of God the Father' (Köstenberger, 1999:121-123; see John 13:1, 3; 14:12, 28; 16:28; 18:37).

In John 1:11, the author specifies the place and the people who have not known Him nor received Him. He came to тò î́ıı and oi íరıoı aủtòv, and here the reader understands the meaning. Many

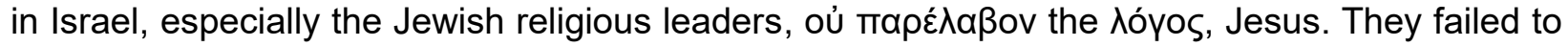
recognize Jesus as the Messiah. They rejected the light including all of the signs He performed which demonstrated His deity and messiahship. Schnackenburg argues that the author's reference 'is not to Jesus' earthly ministry but to Israel's history prior to the incarnation' of Jesus (Schnackenburg, 1990:256). ${ }^{15}$ However, the reference is more likely anticipating the Nóyos's

\footnotetext{
${ }^{13}$ First, John the Baptist was not the light in (John 1:19-27). Second, John came to give witness to the light (John 1:29-34). Third, through John's agency all might become believers (John 1:35-37; see Dodd 1953:248-249).

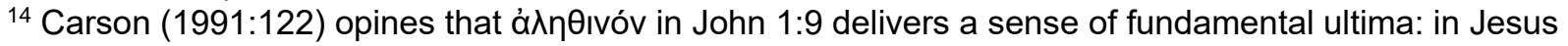
'God has revealed himself in an escalated, eschatological sense'.

${ }^{15}$ Brown (1966:30) agrees with Schnackenburg, citing the parallel of Wisdom in 1 Enoch 42:2.
} 
incarnation in John 1:14 (Culpepper, 1980:13-14; Carson, 1991:122; Ridderbos, 1997:43; Moloney, 1998:37). Anyway, the author underscores the irony of the world - His own people rejecting the One through whom it was made. They reject 'Jesus' claim of equality with God and His revelation of the God the Father' through the words He spoke and the signs He demonstrated. Brown points out, "The basic sin in John's gospel is the failure to know and believe in Jesus" (Brown, 1966:10). The entire Johannine narrative is taken up with the story of the confrontation between the Jews and Jesus as it appears in narratives of the anonymous minor characters of John 4, 5, and 9.

The message of a negative response was found for the first time in John 1:5. However, the negative response from those to whom the Aóyos came (John 1:11) is complemented by the positive response of others, and results of such a response (John 1:12-13). The author places the

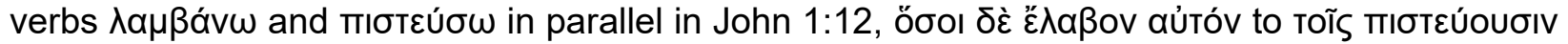

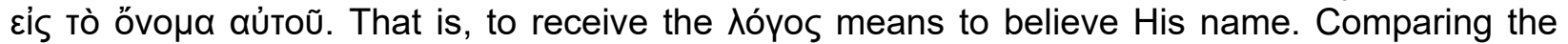

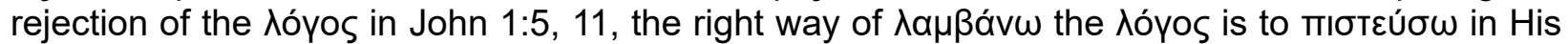

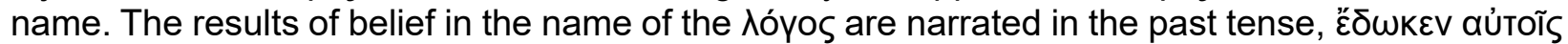

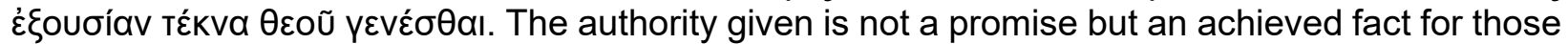

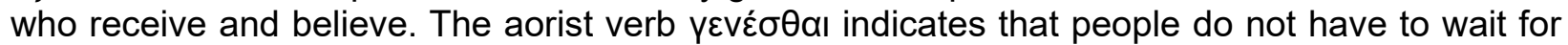
the end times to become God's children. The authority to become God's children is available now to the believers. It can be realized and confirmed.

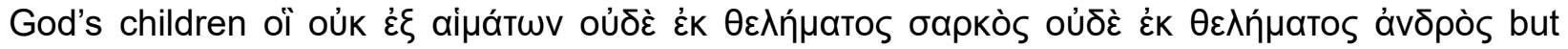

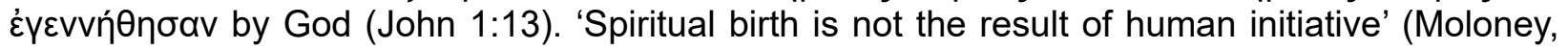
1998:38), but 'of a supernatural origin' (Schnackenburg, 1990:263). The author expresses natural

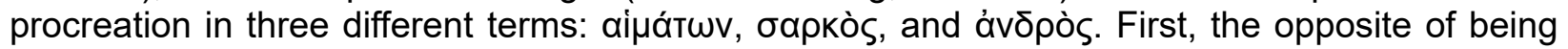
born of God is born by aijúx $\omega v$. The natural descent renders a blood relationship. The author's point is that being a child of God is not a result of blood relations, like a Jew who could simply presume to be a descendant of Abraham. Rather, by His sovereign grace it 'must be sought and received from God on the basis of faith' in Jesus, the Messiah (Borchert, 1996:118). Second, the

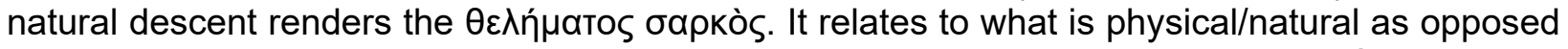
to what is spiritual/supernatural. Third, the natural descent renders $\theta \varepsilon \lambda \hat{\mu} \mu \alpha T o \zeta$ ávס̄òs. The reference to $\theta \varepsilon \lambda \hat{n} \mu \alpha T о \zeta$ ávס̄ò implies the Old Testament 'concept of male headship, in the present context perhaps with reference to the initiative usually taken by the husband in sexual intercourse' resulting in parental determination or will (Borchert, 1996:118).

The author gives his readers the opportunity to see the world in its rebellion, as illustrated in the

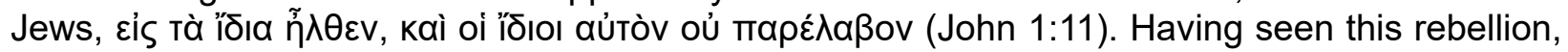
the readers of the Johannine community are challenged to receive and believe Him as they admit their sin and be saved.

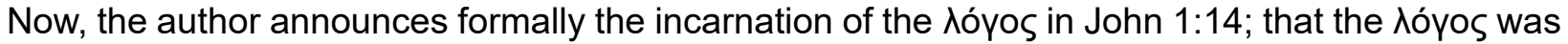
coming into the world has already been mentioned in John 1:3-4, 9. Now it is thus restated,

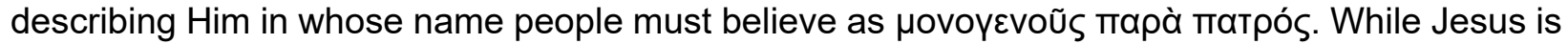
the only begotten Son of God, God is the Father. The matń $\rho$ is a more personal term than $\theta \varepsilon o ́ s$. The author prefers татń $\rho$ in referring to God in his narrative. As anyone who believes in Jesus becomes God's children, Jesus taught his disciples to call God matńp as well (Matthew 6:9).

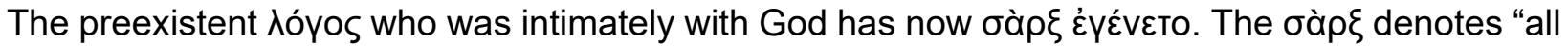
of human person in creaturely existence as distinct from God" (Ridderbos, 1997:49; see also

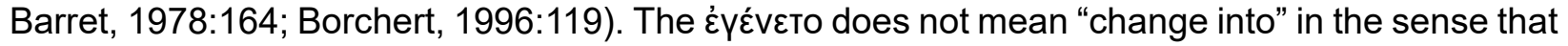


Jesus ceased to be God by becoming a human being (Köstenberger, 2004:40). Nor does it mean He "appeared human or even took on humanity" (Morris, 1995: 90-91). ${ }^{16}$ The narrator's point is that God has now 'chosen to be with His people in a more personal way than ever before' (Carson,

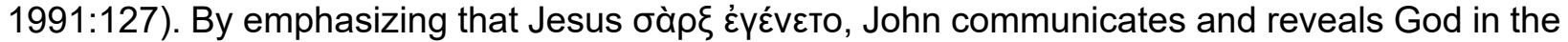

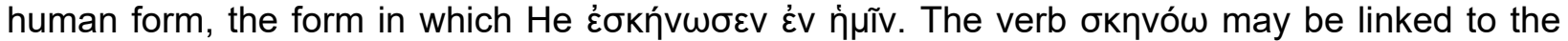
Hebrew verb sakan used of the dwelling of YHWH in Israel (Exodus 33:9; 40:34-35) and root of an important word in Judaism to speak of the resting of the kabod (glory) of YHWH over the tabernacle. In the New Testament it is used outside of this instance only in the Book of Revelation $7: 15 ; 12: 12 ; 13: 6 ; 21: 3$. The phrase 'suggests that in Jesus, God has come to take up residence among His people' in a way more intimate than when He dwelt in the tabernacle. People now may 'meet God and hear Him' in the incarnated Nóyos, Jesus, who took the place of the temple (Mowvley, 1984:136).

By speak of "His dwelling," the author points to the experience of the Johannine community that

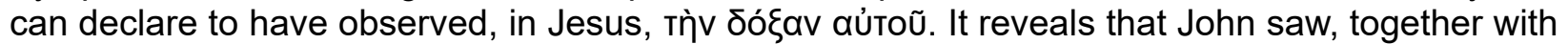
the believing community, the $\delta o ́ \xi \alpha$ of God. The $\delta o ́ \xi \alpha$ is a very important concept in the Johannine narrative, introduced by the author in the Prologue. In the Old Testament, the $\delta$ ó $\xi \alpha$ of God was

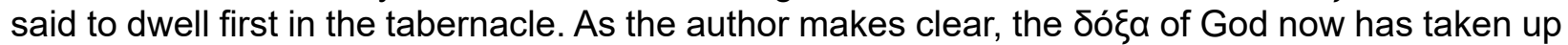
residence among His people once again in Jesus. The author's doxological point of view in his narrative is that Jesus' supreme purpose is to bring glory to God, shown even in the anonymous

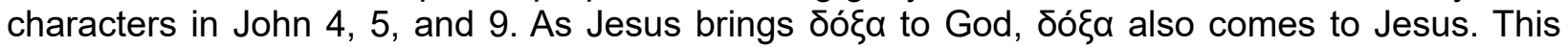

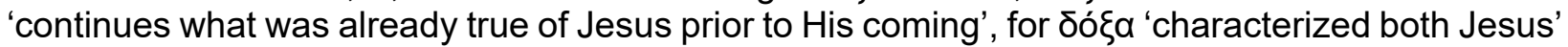
eternal relationship with God' (John 17:5; Carson, 1991:128), and His pre-incarnate state (John $12: 41$ ). While in the world, Jesus' $\delta$ ó $\alpha$ is manifested to His disciples through His signs (cf. John

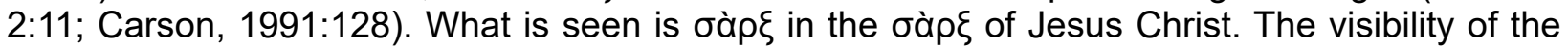
$\sigma \alpha ̀ \rho \xi$ is precisely the point. Of course, the reader sees the ठó $\alpha$ spiritually, but physical sight was also required. In the author's word, unlike Thomas who needed to see for himself before he would believe, the fact that Jesus speaks to those who do not see yet are still able to come to believe demonstrates that people can believe without seeing (John 20:29). That said, people who must believe without seeing need the testimony of those who saw, which is the reason given by the author for having written his gospel.

The author asserted that that the óyos and God have had an intimate relationship from the beginning of history (John 1:1-2), enabling him to proclaim that observing the incarnation of the

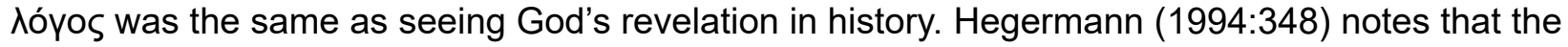

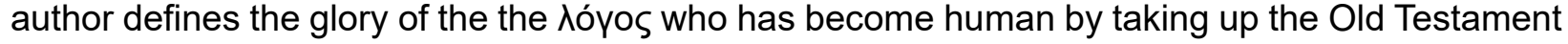
conceptual pair "grace and truth" with which the nature of the glory of Jehovah is summarized.

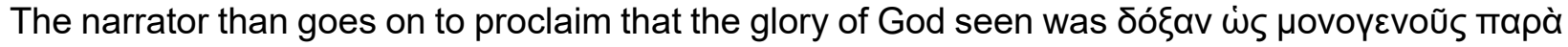

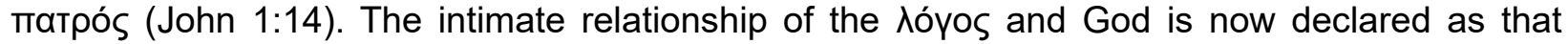
between the only begotten Son and Father, a relationship foundational for the Johannine narrative which is about to begin. The author, however, carefully maintains a distinction between the only begotten Son and the Father, as shown in John 1:1-2. Moloney (1998:39) opines: "The glory that the Son had with the Father before all time (cf. 17:5) is unknown and unknowable to the human situation (cf. 1:18). The author states that what the human story can see of the divine has been seen in the incarnation of the Word, the only Son from the Father." Believers cannot see the $\delta$ ó $\xi \alpha$ of the Father in the Son, but rather $\delta$ ó $\xi \alpha \dot{\omega} \varsigma .{ }^{17}$ His $\delta o ́ \xi \alpha$ fully reflects the $\delta o ́ \xi \alpha$ of the Father.

\footnotetext{
${ }^{16}$ However, Witherington (1995:55) suggests that Jesus took on humanity.

17 Ridderbos (1997:53; see also Schnackenburg 1990:270) renders ws as "in keeping with his nature as",
} 


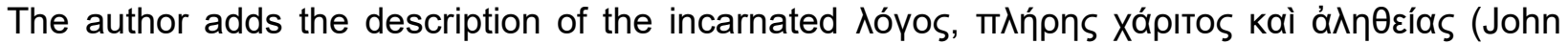

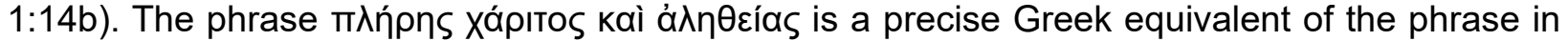
the Old Testament Exodus 34:6, "The Lord, the Lord, the compassionate and gracious God, slow to anger, abounding in love and faithfulness." In this expression, both refer to God's 'covenant faithfulness to His people Israel' (Laney, 1992:44). But it is also possible that the xápıs in the Prologue retains its original meaning of an undeserved favor. The reader or implied reader of the

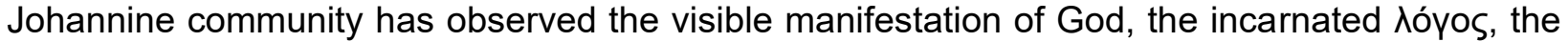
only begotten Son from the Father, the fullness of the xápı sthat is tò $\varphi \tilde{\omega} \varsigma$ Tò á $\lambda \eta \theta ı v o ́ v$. According to the author, God's covenantal faithfulness found ultimate expression in God's sending His only begotten Son, Jesus (Laney, 1992:44).

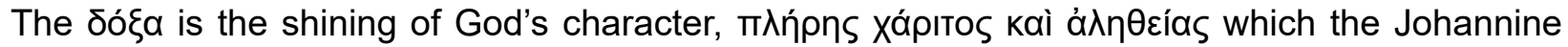
community has seen in the incarnated $\lambda$ óyos, Jesus Christ, and in His life. It is intimately connected with His revelation. The author is directly alluding to the divine aspect of His being and to its revelation as such. When Jesus Himself says that the hour has come for the Son of Man to be glorified (John 12:23), He is pointing to His own death and to His death understood as the

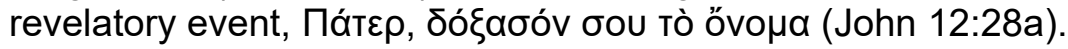

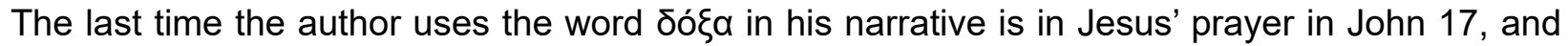
again the reference is to Jesus' disciples seeing His $\delta o ́ \xi \alpha$ (John 17:24). Thus, Jesus' disciples

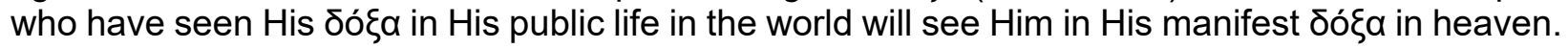
It will include the Johannine community and, of course, all believers.

\section{John's witness concerning the Word's preeminence (John 1:15)}

In John 1:15 $\mathrm{t}$ thee author turns to the witness of John the Baptist. The first description of the

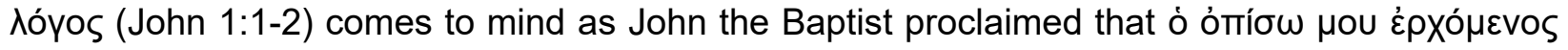
follows him in terms of the time sequence of events (John 1:15a), but, in terms of His place in

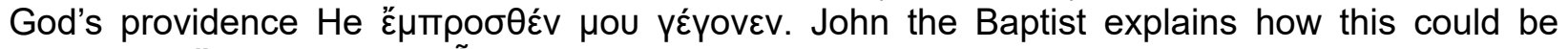

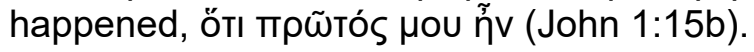

John the Baptist serves as the prototype of the Old Testament prophetic witness to Jesus 'which makes his testimony an integral part of the salvation history' unfolded and described by the author (Brodie, 1993:143). In this regard, that Brodie states John the Baptist appears to be the embodiment of the Old Testament is 'far from being an illogical interpolation', but instead is altogether appropriate. 'It is as though, when the incarnation finally arrived, full of covenant love, the OT stood up and cheered' (Brodie, 1993:143).

John the Baptist was "six months older than Jesus" (Luke 1:24, 26) and began his ministry before Jesus did' (Luke 3:1-20; ). Like much of Eastern culture, the Old Testament supports 'the notion that rank and honor is tied to one's age' (Kruze, 2003:791); thus, even a six-month difference implied preeminence (Harrison, 1988:791). Because of John the Baptist's age and earlier ministry, the author shows that Jesus was really при̃тós him, and therefore legitimately to be honored above him.

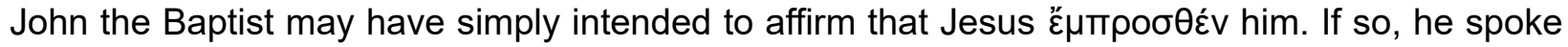
better than he knew (Kruse, 2003:72). Interestingly, John the Baptist's witness is anticipated here

while Brown (1966:13) renders it as "in the quality of". 
prior to its actual narration in John 1:19-34 (Ridderbos 1997:55).

\section{The final revelation brought by Jesus Christ (John 1:16-18)}

The author leads the readers to a final revelation of people's reception and response to the gift of the incarnated $\lambda$ óyos, Jesus Christ. To the readers of Johannine community, the author explains

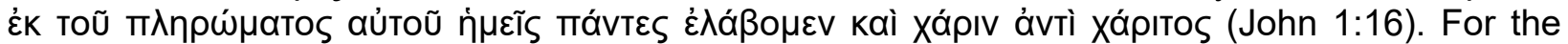
Johannine narrative the believers receive His $\pi \lambda \eta \rho \omega ́ \mu \alpha$ within their hearts. They receive a xápıs that completes a former xápı.$^{18}$ The $\pi \lambda \eta \rho \omega ́ \mu \alpha$ can be found in only the xápı of God displayed in Jesus, 'whose purpose was to bring life abundantly' (John 10:10; Borchert, 1996:123).

The author explains these two graces and their relationship in John 1:17. These two graces have

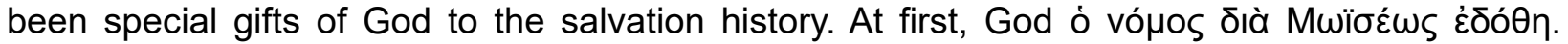

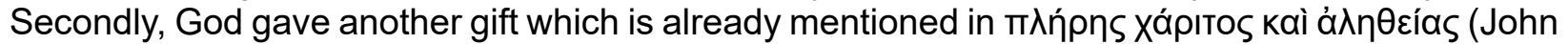

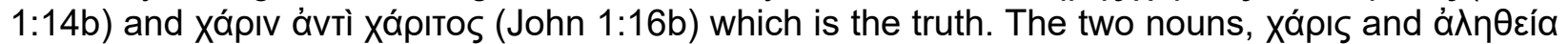

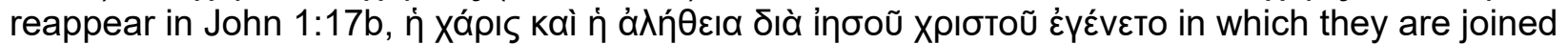
by kaì. The Xápı that is truth supersedes and completes the first Xápı given through Moses, and

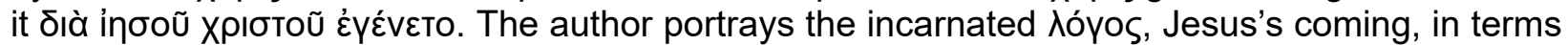
of the giving of XápIV ávì Xápıтos, affirming that the 'grace given through Moses was replaced by the grace bestowed through Christ' (Mowvley, 1984:137). This does not mean to nullify the first Xápıs, rather it respects it. The author claims that the first xápı is now completed in the final xápıৎ

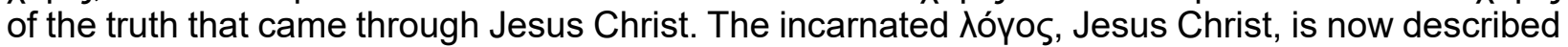
as the perfection of God's gifts. The author tells the reader or implied reader $\pi \lambda$ ńpnऽ xápıтоऽ кaì á $\lambda \eta \theta \varepsilon i ́ a s$, the perfect grace is 'found in Jesus Christ. Jesus' ministry is superior to that of Moses' (Mowvley, 1984:137). However, the Jewish religious leaders such as the Pharisees, calling themselves disciples of Moses (John 9:28), are furiously against the author's claim. Jesus counters by noting says that Moses wrote of Him (John 5:46-47). Although the law is God's gracious revelation, it is not adequate as an instrument of the truth, the ultimate grace that came through Jesus Christ.

The author makes one more point before he turns to the narrative as he concludes the prologue. Although the Johannine community may claim to have seen the revelation of God's סó $\xi \alpha$ in the

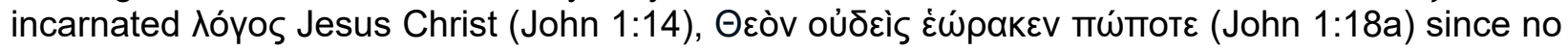
one can see the face of God and live, as Moses and others in the Old Testament narratives learned. That is, no one except the One who has told the story of God's way $\dot{\xi \eta ү \eta ́ \sigma a t o, ~ a n d ~ i s ~}$

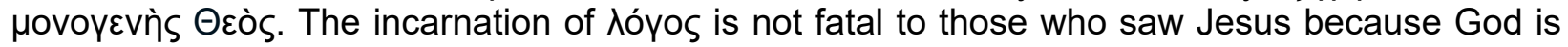
manifested in flesh. The glory that was hidden in the cloud in the Old Testament narratives remain hidden, now veiled in flesh, but the veil is of a kind that permits a visible form of revelation.

John 1:18 constitutes an inclusio with John. 1:1 (Keener, 2003:335-338). There it was said that

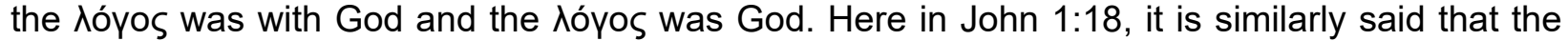

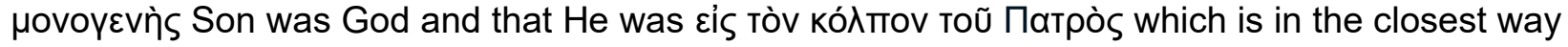
possible He could be with God (Louw, 1968:38).

The reason human beings cannot see God is that God is spirit, and all human beings are sinners,

\footnotetext{
${ }^{18}$ kaì Xápıv ơviì Xápıтoৎ has generally rendered the sense of "grace upon grace" by translating the proposition óviì as "upon," so its meaning of an abundance of grace. However, it has been questioned by some scholars, and Moloney, for example, renders xápıs as "a gift" that allows áviì to keep its meaning of "a gift in place of a gift" (see Moloney, 1998:46).
} 
in direct contrast to God as holy and sinless. However, the incarnated Nóyos, Jesus, is Himself God, and He became a human being so that people could see God in Him (John 1:14). Although

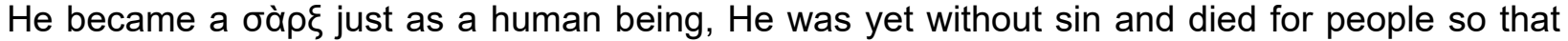
their sinfulness no longer prevents them from having fellowship with God (John 1:29). As the author shows later in his narrative, Jesus' claim of deity brought Him into conflict with the Jewish religious leaders. This results in His crucifixion under the charge of blasphemy (John 19:7).

Bauckham (2015:50) summarizes well this last section of the prologue in which the author presents the incarnated Aóyos, the Son Jesus Christ as "the eschatological fulfillment of the Sinai covenant, a revelation of glory that fulfills the Sinai covenant by qualitative surpassing it."

The author conveys that the incarnated tóyos, the Son of God, will focus on the Father throughout his narrative to follow. The preexistent relationship between Nóyos, the Son Jesus Christ, and God

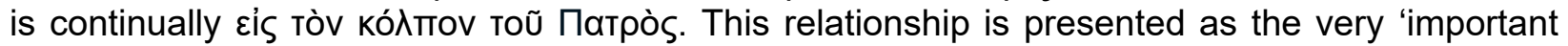
reason' why the incarnated Aóyos 'was able to overcome' the immeasurable chasm that had existed between God and man up to that point despite the law. This utmost intimacy of Jesus' relationship with the Father enabled Him to reveal the Father in an unprecedented way (Brown, 1966:36).

Köstenberger (2004:50) states that the author makes the important point that the entire narrative to follow 'should be read as an account of Jesus "telling the whole story" of God the Father' as he concludes the Prologue.

\section{Conclusion}

The author of the Johannine narrative in his opening prologue sets for a range of theological point of views, consisting of mainly Christological themes such as $\lambda$ óyos preexisted creation with God, becomes flesh, the incarnation of God, equality with God but personal distinction between them, the ultimate intimacy in relationship with God the Father, the true light of divine revelation and the Savior of the world.

The One of the purposes of the prologue is to indicate to the readers how they should read the life story of Jesus within a context that begins with the Old Testament, as seen with the near literal repeating of the opening words of Genesis in the gospel of John. The author presents the incarnation of the גóyos Jesus Christ as the ultimate fulfillment of the Mosaic covenant, a revelation of glory that fulfills it unprecedentedly. He affirms that the Johannine community has access to the perfection of the former gift. They can see the revelation of the glory in His Son, Jesus Christ. Thus, the reader can also see the author's doxological point of view in the midst of his Christological themes. With the prologue the author wants to make clear that God has been made known in and through Jesus Christ. "Only the Son, Jesus Christ has ever seen God, and the story of His life will tell the story of God's loving action within the human history" (Moloney, 1988:41). Culpepper comments with regard to the relationship to the rest of the narrative, "In the Prologue, the narrator speaks, introducing the reader to the protagonist (Jesus), clarifying His origin and identity, and foreshadowing the plot and the themes of the story, that is about to be told." (Culpepper, 1998: 116-17).

\section{References}

Barrett, C.K. (1978). The gospel according to St. John: An introduction with commentary and notes on the Greek text, SPCK, London. 
Bauckham, R. (1998). God crucified: Monotheism and Christology in the New Testament, William B. Eerdmans Publishing Company, Grand Rapids.

Bauckham, R. (2015). Gospel of glory: Major themes in Johannine theology, Baker Academic, Grand Rapids.

Borchert, G.L. (1996). John 1-11: An exegetical and theological exposition of Holy Scripture, Broadman \& Holman Publishing Group, Nashville.

Brodie, T.L. (1993). The gospel according to John: A literary and theological commentary, Oxford University Press, New York.

Brown, R.E. (1966). The gospel according to John I-XII, Anchor Bible, Garden City.

Carson, D.A. (1991). The gospel according to John, Inter-Varsity Press, Grand Rapids.

Culpepper, R.A. (1980). 'The pivot of John's prologue', New Testament Studies, 27(1), 1-31.

Culpepper, R.A. (1983). Anatomy of the Fourth Gospel, Fortress Press, Philadelphia.

Culpepper, R.A. (1988). The Gospel of John, Fortress Press, Philadelphia.

Dodd, C.H. (1953). The interpretation of the Fourth Gospel, Cambridge University Press, Cambridge.

Harris, W.H. (1994). 'A theology of John's writings', in R.R. Zuck (ed.), A Biblical theology of the New Testament, 99. 167-242, Moody Press, Chicago.

Harrison, R.K. (1988). The Baker Encyclopedia of the Bible, vol. 1, Baker Academic, Grand Rapids.

Hegermann, H. (1994). 'ঠóła', in H. Balz \& G. Schneider (eds.), Exegetical dictionary of the New Testament, William B. Eerdmans Publishing Co., Grand Rapids, vol.1, p. 348.

Keener, C.S. (2003). The gospel of John: A commentary, vol. 1, Hendrickson Publishers, Peabody.

Kim, S.S. (2009). 'The literary and theological significance of the Johannine prologue', Bibliotheca Sacr, 166(664), 421-435.

Köstenberger, A.J. (1999). Encountering John: The gospel in historical, literary, and theological perspective, Baker Academic, Grand Rapids.

Köstenberger, A.J. (2004). John, Baker Academic, Grand Rapids.

Kruse, C.G. (2003). The gospel according to John: An introduction and commentary, vol. 4, InterVarsity Press, Leicester.

Laney, J.C. (1992). John, Moody Publishers, Chicago. 


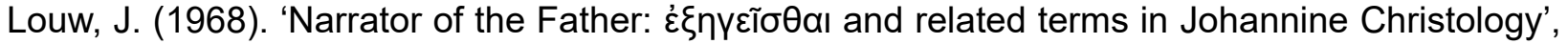
Neotestamentica, 2, 32-40.

MacLeod, D.J. (2003). 'The eternality and deity of the Word: John 1:1-2', Bibliotheca Sacra, 160(637), 48-64.

Moloney, F.J. (1993). Belief in the Word: Reading the Fourth Gospel: John 1-4, Fortress Press, Minneapolis.

Moloney, F.J. (1998). The gospel of John, Liturgical Press, Collegeville.

Morris, L. (1995). The gospel according to John, Revised, William B. Eerdmans Publishing Company, Grand Rapids.

Mowvley, H. (1984). 'John 1:14-18 in the light of Exodus 33:7-34: 35', The Expository Times, 95(5), 135-137.

Ridderbos, H.N. (1997). The gospel according to John: A theological commentary, William B. Eerdmans Publishing Company, Grand Rapids.

Schnackenburg, R. (1990). The gospel according to St. John, Crossroad Publishing Company, Spring Valley.

Seo, Y.H. (200). Analysis of the New Testament structure II, transl. N. Hahn, vol. II, Gyung Hyung Press, Seoul.

Smith, D.M. (1995). The theology of the gospel of John, Cambridge University Press, Cambridge.

Witherington, B. (1995). John's wisdom: A commentary on the Fourth Gospel, Westminster John Knox Press, Louisville. 